\title{
The efficiency of written final exam questions in mathematics based on voluntary data reports, 2012-2015
}

\author{
Csaba Csapodi and Levente Koncz
}

\begin{abstract}
The efficiency of each question in the mathematics written final exam is not recorded by the institutions organizing the graduation exam. In order to overcome this deficiency the committee of final exams in mathematics and the Hungarian Educational Authority ask schools to send - beyond the total marks obtained on the paper - the scores of each question of all individual candidates to the Authority every year since 2012. Because a high proportion of schools complied with this request between 2012 and 2015, the researchers were provided valuable information for a deeper analysis on the effectiveness of exams. In this paper we have carried out an analysis of the efficiency of questions set in the written examination papers both on the intermediate and on the higher level in the last four years, on the basis of these voluntary data reports.
\end{abstract}

Key words and phrases: final exam results in mathematics, analysis of the efficiency of problems, efficiency of different topics.

ZDM Subject Classification: B10, D60, U40.

\section{Introduction}

The research of the efficiency ${ }^{1}$ of the questions on the written final exams is an important issue. The Hungarian Educational Authority (Oktatási Hivatal, $\mathrm{OH}$ ) each year publishes some of the data related to the exam on its website [1]. The problem is that the available tables contain only the aggregate score of

${ }^{1}$ In this paper efficiency of a question is meant to be the average score of all candidates expressed in percentages of the total score of the given question.

Copyright (C) 2016 by University of Debrecen 
part I and part II of all candidates both on the intermediate and on the higher level, not the scores of each question. So it is very difficult to determine the difficulty level of different topics and the reliability of different types of exercises, although it would support the decisions of the committee of final exams. This is an important question as - for safety reasons - it is not possible to calibrate and test the examination papers beforehand, hence the members of the committee and the lectors can only rely on their own experiences and intuitions, when compiling the papers. Looking at data from the past nine years we can establish that the overall efficiency of the written exam on both levels shows little fluctuation, as shown in Figure 1. Nevertheless it is desirable that the preparation of the examination papers - measuring approximately 80000 candidates a year - is carried out using as much information as possible.

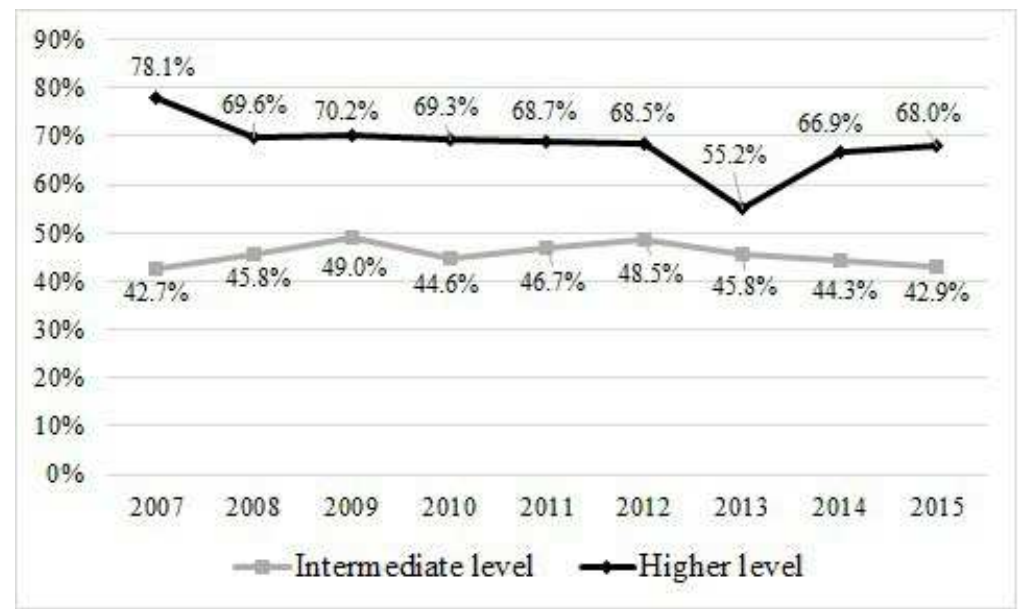

Figure 1. The average efficiency of written exams on intermediate and higher level 2007-2015

\section{Research questions}

In our research we would like to answer the following questions:

1. At what topics do the candidates perform better and which ones are causing more difficulties?

2. What is the efficiency of the topics (logic, graphs, statistics, probability theory), which are relatively new in the mathematics curriculum in Hungary? 
3. What is the efficiency of the problems related to everyday life situations of which some also requires modeling? (These kind of problems occur more frequently in the current examination papers on both levels than they did before 2005.)

4. Are there topics, where those intermediate level candidates whose performance is the worst (under 20\%) are more efficient or less efficient than their average efficiency?

We believe that the answers to these questions may be of interest not only for the members of the final exam committee, but also for all secondary school teachers who want to prepare their students for the final exam as effectively as possible.

\section{The research methodology}

Every year since 2012 - after the end of the final exam period in May and June - the Hungarian Educational Authority (through the system ADAFOR) invites schools organizing the final exams to record the scores of each candidate's each question in a spreadsheet designed specifically for this purpose. Fortunately a large number of the invited schools fill in this table every year. After processing the data a brief analysis of the experiences is made available for the schools by the Educational Authority.

The following tables indicate the number of all candidates and of those participating in the voluntary data reports, and the average efficiency of both groups. (In the voluntary data report only those examinees take part, who take their final exam in Hungarian in the exam period in May and June each year. Regarding the higher level data we can presume that the rate of feedback is a bit lower because there is a greater proportion of examinees among them, who registered for their exams at Government Offices, from whom data has not been requested.)

Although - strictly speaking - incoming data through voluntary reporting cannot be considered to be representative, but the large sample allows valid conclusions concerning all candidates. The validity of these data is also supported by another fact: for the purpose of the detailed analysis of the 2012 written exams [2] (conducted by the Educational Authority) when a representative sample of data was selected ( $n=996$ on the intermediate and $n=596$ on the higher level), and the efficiency data also showed a strong correspondence with data from the 
Table 1. The overall average efficiency of written exams on intermediate level 2012-2015

\begin{tabular}{|c|c|c|c|c|}
\hline & \multicolumn{2}{|c|}{ All candidates } & \multicolumn{2}{c|}{ Voluntary data report } \\
Year & $\begin{array}{c}\text { number of } \\
\text { examinees }\end{array}$ & $\begin{array}{c}\text { average } \\
\text { efficiency }\end{array}$ & $\begin{array}{c}\text { number of } \\
\text { examinees }\end{array}$ & $\begin{array}{c}\text { average } \\
\text { efficiency }\end{array}$ \\
\hline $\mathbf{2 0 1 2}$ & 81132 & $\mathbf{4 8 . 5 \%}$ & $31092(38.3 \%)$ & $\mathbf{4 9 . 4 \%}$ \\
\hline $\mathbf{2 0 1 3}$ & 75740 & $\mathbf{4 5 . 8 \%}$ & $25899(34.2 \%)$ & $\mathbf{4 7 . 1 \%}$ \\
\hline $\mathbf{2 0 1 4}$ & 74876 & $\mathbf{4 4 . 3 \%}$ & $27263(36.4 \%)$ & $\mathbf{4 6 . 1 \%}$ \\
\hline $\mathbf{2 0 1 5}$ & 72025 & $\mathbf{4 2 . 9 \%}$ & $24209(33.6 \%)$ & $\mathbf{4 4 . 6 \%}$ \\
\hline
\end{tabular}

Table 2. The overall average efficiency of written exams on higher level 2012-2015

\begin{tabular}{|c|c|c|c|c|}
\hline \multirow[b]{2}{*}{ Year } & \multicolumn{2}{|c|}{ All candidates ${ }^{2}$} & \multicolumn{2}{|c|}{ Voluntary data report } \\
\hline & $\begin{array}{l}\text { number of } \\
\text { examinees }\end{array}$ & $\begin{array}{c}\text { average } \\
\text { efficiency }\end{array}$ & $\begin{array}{l}\text { number of } \\
\text { examinees }\end{array}$ & $\begin{array}{l}\text { average } \\
\text { efficiency }\end{array}$ \\
\hline 2012 & 3446 & $68.5 \%$ & $818(23.7 \%)$ & $74.1 \%$ \\
\hline 2013 & 3690 & $55.2 \%$ & $1046(28.3 \%)$ & $61.9 \%$ \\
\hline 2014 & 3531 & $66.9 \%$ & $1062(30.1 \%)$ & $73.1 \%$ \\
\hline 2015 & 3403 & $68.0 \%$ & $920(27.0 \%)$ & $73.0 \%$ \\
\hline
\end{tabular}

voluntary report (the correlation coefficient on the intermediate level is 0.997 and on the higher level 0.994).

We should note, that each year the average efficiency of all candidates is lower than the results from the voluntary reports (the difference is 1-1.5 percentage point on the intermediate, 3-4 percentage points on the higher level). The exact cause of this phenomenon is unknown to us, but it is possible that the better performing schools are more likely to provide data. The reason for the bigger difference on the higher level may be that the voluntary report does not contain the results of those candidates who register for their exams at Government Offices, where the results are usually lower than the national average.

The examination papers can be accessed on the webpage of the Educational Authority [3].

${ }^{2}$ Data of the written exams of candidates sitting their exams on Hungarian language in MayJune 
4. Presenting the results of the research, analysis of data

\subsection{Intermediate level, Part I}

The most information can be obtained from the data of Part I of the intermediate level exam, as here we have all the efficiency data of the 2-4 point problems.

Table 3 shows all the 48 questions between 2012 and 2015: their topic, their average efficiency and whether it required the candidate to give a detailed reasoning beyond the solution.

Based on the data of Table 3 we can state that:

- High efficiency (over $80 \%$ ) is characteristic of the problems of sets, graphs and simple percentages.

- Good efficiency (65-80\%) is characteristic of the problems of statistics, simple probability and some problems of functions.

- Low efficiency (under 40\%) is detected among geometrical problems. The lowest efficiency $(32 \%)$ was recorded in a question, where the candidate was asked to deduce the equation of a line passing through a given point, parallel to a given line. This is one of the most basic problems in coordinate geometry.

- Out of 48 problems 35 did not ask the candidate to give a detailed reasoning, the average efficiency of these questions is $65 \%$. The problems requiring reasoning (apart form 2014/7) all resulted under 70\%, the average efficiency of these 13 problems being $54 \%$.

Table 4 summarizes all questions of this part of the exam, grouped by topics. This was a clear case at almost every question, one or two of them could have been classified under two separate topic groups.

Based on the data of Table 4 we can state that:

- One of the new features of the two-level final exams in mathematics was that problems of the first and fifth topic group in Table 4 were given greater emphasis. It's quite clear that these problems are among the most successful ones.

- One of the "classical" topics (which has lost some of its importance in the education of mathematics in the last decades), geometry, especially coordinate geometry, causes the most difficulties for students. 
Table 3. The topic and the average efficiency of the problems of Part I in the intermediate level written final exam, 2012-2015

\begin{tabular}{|c|c|c|c|c|c|}
\hline Topic group & Topic & Year & $\begin{array}{l}\text { Number } \\
\text { of the } \\
\text { question }\end{array}$ & $\begin{array}{l}\text { Effici- } \\
\text { ency }\end{array}$ & $\begin{array}{l}\text { Detailed } \\
\text { answer }\end{array}$ \\
\hline \multirow{9}{*}{$\begin{array}{l}\text { Methods of } \\
\text { mathematical } \\
\text { reasoning }\end{array}$} & \multirow{2}{*}{ Operations on sets } & 2013 & 1 & $93 \%$ & \\
\hline & & 2014 & 1 & $83 \%$ & \\
\hline & Cardinality of sets & 2014 & 5 & $85 \%$ & \\
\hline & \multirow{3}{*}{ Mathematical logic } & 2012 & $\frac{4}{8}$ & $48 \%$ & \\
\hline & & $\frac{2013}{2015}$ & $\frac{8}{3}$ & $\frac{33 \%}{53 \%}$ & \\
\hline & & 2015 & 5 & $39 \%$ & \\
\hline & Combinatorics & 2013 & 10 & $62 \%$ & yes \\
\hline & \multirow{2}{*}{ Graphs } & 2014 & 10 & $85 \%$ & \\
\hline & & 2015 & 8 & $87 \%$ & \\
\hline \multirow{10}{*}{ Algebra } & \multirow{2}{*}{$\begin{array}{l}\text { Algebraic fractions } \\
\text { Formulas }\end{array}$} & 2012 & 11 & $53 \%$ & \\
\hline & & $\frac{2015}{2012}$ & $\frac{1}{8}$ & $45 \%$ & \\
\hline & \multirow{2}{*}{ Logarithm } & 2012 & 10 & $42 \%$ & yes \\
\hline & & 2014 & 9 & $55 \%$ & \\
\hline & \multirow{2}{*}{ Quadratic equation } & 2014 & 3 & $69 \%$ & yes \\
\hline & & 2015 & 4 & $45 \%$ & yes \\
\hline & Number theory & $\frac{2014}{2015}$ & $\frac{7}{2}$ & $\frac{81 \%}{010 \%}$ & yes \\
\hline & \multirow{3}{*}{ Percentages } & 2012 & 5 & $91 \%$ & \\
\hline & & 2014 & 2 & $85 \%$ & \\
\hline & & 2014 & $\overline{6}$ & $59 \%$ & yes \\
\hline \multirow{8}{*}{ Functions } & \multirow{4}{*}{$\begin{array}{l}\text { Characteristics of } \\
\text { functions }\end{array}$} & 2012 & 3 & $56 \%$ & \\
\hline & & 2013 & 7 & $37 \%$ & yes \\
\hline & & 2014 & 4 & $70 \%$ & \\
\hline & & 2015 & 6 & $59 \%$ & \\
\hline & \multirow{2}{*}{$\begin{array}{l}\text { Transformation of } \\
\text { functions }\end{array}$} & 2012 & 12 & $51 \%$ & \\
\hline & & $\frac{2013}{2014}$ & $\frac{4}{8}$ & $\frac{66 \%}{73 \%}$ & \\
\hline & \multirow{2}{*}{ Geometric progression } & 2012 & 1 & $60 \%$ & \\
\hline & & 2015 & 9 & $50 \%$ & \\
\hline \multirow{8}{*}{ Geometry } & \multirow{2}{*}{ Elementary geometry } & 2014 & 11 & $60 \%$ & yes \\
\hline & & 2012 & 6 & $70 \%$ & \\
\hline & Trigonometry & 2013 & 5 & $54 \%$ & yes \\
\hline & Solid figures & 2013 & 9 & $34 \%$ & \\
\hline & Vectors & 2015 & 11 & $36 \%$ & \\
\hline & Equation of a line & 2012 & 2 & $32 \%$ & yes \\
\hline & & $\frac{2013}{2012}$ & $\frac{b}{7}$ & $\frac{36 \%}{55 \%}$ & \\
\hline & Equation of a circle & 2015 & 10 & $60 \%$ & \\
\hline \multirow{7}{*}{$\begin{array}{l}\text { Statistics, } \\
\text { probability }\end{array}$} & \multirow{3}{*}{ Descriptive statistics } & 2013 & 3 & $65 \%$ & yes \\
\hline & & 2013 & 11 & $84 \%$ & \\
\hline & & 2015 & 7 & $74 \%$ & \\
\hline & \multirow{4}{*}{ Probability } & $\frac{2013}{2012}$ & $\frac{2}{9}$ & $\frac{72 \%}{51 \%}$ & ves \\
\hline & & 2013 & 12 & $76 \%$ & \\
\hline & & 2014 & 12 & $78 \%$ & \\
\hline & & 2015 & 12 & $48 \%$ & \\
\hline
\end{tabular}


Table 4. The distribution by topic and the average efficiency (weighted by their total marks) of the problems of Part I in the intermediate level written final exam, 2012-2015

\begin{tabular}{|l|c|c|}
\hline Topic group & $\begin{array}{c}\text { Number of } \\
\text { questions } \\
2012-2015\end{array}$ & $\begin{array}{c}\text { Average } \\
\text { efficiency }\end{array}$ \\
\hline Methods of mathematical reasoning & 10 & $\mathbf{6 8 \%}$ \\
\hline Algebra & 12 & $\mathbf{6 6 \%}$ \\
\hline Functions & 9 & $\mathbf{5 6 \%}$ \\
\hline Geometry & 9 & $\mathbf{4 8 \%}$ \\
\hline Statistics, probability & 8 & $\mathbf{6 6 \%}$ \\
\hline
\end{tabular}

\subsection{Intermediate level, Part IIA}

Part IIA of the intermediate level written final exam consists of 3 questions, each worth 9-14 points. These questions usually include sub-questions from the same topic group, but there are exceptions to this principle.

Table 5 shows all the 12 questions between 2012 and 2015: their topic(s), their average efficiency based on the voluntary report and whether the given problem was related to everyday life situations, requiring simple modeling.

Based on Table 5, interesting observations may be presented again, although their importance is reduced, as only the score for the whole questions is available, we don't have information about the separate efficiency of the sub-questions.

- Certain types of problems produce very similar efficiency in different years. Such is the topic of progressions (arithmetic and geometrical): the average efficiency of problems 2013/13, 2014/15, partly 2015/15 were all between $41 \%$ and $44 \%$. Moreover, the efficiency of question c) of problem 2012/15 (from a topic very similar to the fore mentioned) is also known: $44 \%$ [2].

- Problems in coordinate geometry produce very low and similar efficiency in this part of the paper as well.

- The worst results are observed in the geometric calculations: the approximately $30 \%$ efficiency means that the majority of candidates hardly scored any points in these problems.

- In those years when a problem related to everyday life, requiring simple modelling was set in this part of the written exam (2012, 2013 and 2015), these questions always produced the highest efficiency among the three questions. 
Table 5. The topic and the average efficiency of the problems of

Part IIA in the intermediate level written final exam, 2012-2015

\begin{tabular}{|c|c|c|c|c|c|}
\hline Year & $\begin{array}{l}\text { Number } \\
\text { of the } \\
\text { question }\end{array}$ & Topic group & Topic & $\begin{array}{l}\text { Effici- } \\
\text { ency }\end{array}$ & $\begin{array}{l}\text { Required } \\
\text { modeling }\end{array}$ \\
\hline \multirow{3}{*}{2012} & 13 & Algebra & Solving equations & $33 \%$ & \\
\hline & 14 & Geometry & $\begin{array}{l}\text { Geometric calculations } \\
\text { in the plane }\end{array}$ & $30 \%$ & \\
\hline & 15 & Functions & $\begin{array}{l}\text { Arithmetic and } \\
\text { geometric progressions }\end{array}$ & $54 \%$ & yes \\
\hline \multirow{3}{*}{2013} & 13 & Functions & $\begin{array}{l}\text { Arithmetic and } \\
\text { geometric progressions }\end{array}$ & $42 \%$ & \\
\hline & 14 & Geometry & $\begin{array}{l}\text { Coordinate } \\
\text { geometry }\end{array}$ & $36 \%$ & \\
\hline & 15 & Algebra & Percentages & $49 \%$ & yes \\
\hline \multirow{3}{*}{2014} & 13 & Geometry & $\begin{array}{l}\text { Coordinate } \\
\text { geometry }\end{array}$ & $37 \%$ & \\
\hline & 14 & Mixed & $\begin{array}{l}\text { Geometric calculations } \\
\text { in the plane } \\
\text { Trigonometric equation } \\
\text { Trigonometric functions }\end{array}$ & $31 \%$ & \\
\hline & 15 & Functions & Arithmetic progression & $41 \%$ & \\
\hline \multirow{3}{*}{2015} & 13 & Geometry & $\begin{array}{l}\text { Geometric calculations } \\
\text { in the plane }\end{array}$ & $34 \%$ & \\
\hline & 14 & Mixed & $\begin{array}{l}\text { Solving equations } \\
\text { Linear functions }\end{array}$ & $41 \%$ & \\
\hline & 15 & Mixed & $\begin{array}{l}\text { Arithmetic progression } \\
\text { Geometric mean }\end{array}$ & $44 \%$ & yes \\
\hline
\end{tabular}

While analyzing the data we have noticed that the efficiency of short, usually "pure" mathematical problems (e.g. 2012/13, 2013/14, 2015/14) is very low, the candidates are more successful in solving problems with a longer text (usually also requiring modelling, e.g. 2012/15, 2013/15, 2015/15). So we have examined the correlation between the number of characters in the text and the efficiency of each question. Surprisingly a relatively strong correlation coefficient (0.76) 
was measured. We know that - because of the low number of data (12) - very definitive conclusions may not be drawn, but it seems that the longer the text of a problem is the better efficiency it has. The candidates seem to be more successful in solving problems, where they have to get relevant information from the text of the problem usually requiring less mathematical knowledge. This statement contradicts the popular belief among teachers about students not being successful in solving problems of longer text, often also requiring modelling.

\subsection{Intermediate level, Part IIB}

Part IIB of the intermediate level written final exam contains 3 questions, worth 17 points each. The candidate has to solve two of the three problems and only those two are marked. These questions usually include sub-questions from different topics.

Table 6 shows all 12 questions of this part of the intermediate level written exam between 2012 and 2015: their topic(s), their average efficiency calculated from the voluntary report, the ratio of candidates who did not choose the given problem (skip ratio), and whether the given problem was related to everyday life situations, requiring modeling.

Based on Table 6 a few observations may be made, although their strength is reduced again, partly because we do not have information about the efficiency of the sub-questions, partly because not all candidates solved all the problems.

- Similarly to Part I, we can say that problems related clearly to methods of mathematical thinking or statistics (e.g. 2012/16, 2012/17, 2013/16) are popular among candidates and produce relatively high efficiency. (As an exception to this problem 2014/18 was embedded to an unusual basic situation - this might have caused its lower efficiency.)

- The most successful sub-question during the examined four-year period was part a) of problem 2012/16, worth 8 points, chosen by $97 \%$ of the candidates, while producing an outstanding efficiency of $95 \%$ [2].

- Examining the problems with longer text is only relevant in 2013: this year $85 \%$ of candidates have chosen this problem to solve, and they attained much better scores than then they did at the two other problems. (The other three years are irrelevant in this context.)

With regard to these 12 questions we have also examined whether there is any connection between the length of the text, the efficiency and the skip ratio of the problems. Basically it turned out that among these criteria only low correlation is 
Table 6. The topic, the average efficiency and the skip ratio of the problems of Part IIB of the intermediate level written final exam, $2012-2015$

\begin{tabular}{|c|c|c|c|c|c|}
\hline Year & $\begin{array}{l}\text { Number } \\
\text { of the } \\
\text { question }\end{array}$ & Topic & $\begin{array}{l}\text { Effici- } \\
\text { ency }\end{array}$ & $\begin{array}{l}\text { Skip } \\
\text { ratio }\end{array}$ & $\begin{array}{l}\text { Required } \\
\text { modeling }\end{array}$ \\
\hline \multirow[b]{3}{*}{2012} & 16 & $\begin{array}{l}\text { Sets } \\
\text { Probability }\end{array}$ & $61 \%$ & $3 \%$ & \\
\hline & 17 & Statistics & $49 \%$ & $21 \%$ & yes \\
\hline & 18 & $\begin{array}{l}\text { Geometric calculations } \\
\text { in the space } \\
\text { Graphs }\end{array}$ & $52 \%$ & $76 \%$ & yes \\
\hline \multirow{3}{*}{2013} & 16 & $\begin{array}{l}\text { Graphs } \\
\text { Probability }\end{array}$ & $55 \%$ & $15 \%$ & yes \\
\hline & 17 & $\begin{array}{l}\text { Exponential and } \\
\text { trigonometric equation, } \\
\text { inequality }\end{array}$ & $40 \%$ & $56 \%$ & \\
\hline & 18 & $\begin{array}{l}\text { Geometric calculations } \\
\text { in the space } \\
\text { Probability }\end{array}$ & $33 \%$ & $29 \%$ & \\
\hline \multirow{3}{*}{2014} & 16 & $\begin{array}{l}\text { Exponential process } \\
\text { Geometric calculations } \\
\text { in the space } \\
\text { Combinatorics }\end{array}$ & $40 \%$ & $46 \%$ & yes \\
\hline & 17 & $\begin{array}{l}\text { Statistics } \\
\text { System of linear } \\
\text { equations }\end{array}$ & $32 \%$ & $21 \%$ & yes \\
\hline & 18 & $\begin{array}{l}\text { Combinatorics } \\
\text { Probability }\end{array}$ & $27 \%$ & $33 \%$ & yes \\
\hline \multirow{3}{*}{2015} & 16 & $\begin{array}{l}\text { Exponential process } \\
\text { Geometric calculations } \\
\text { in the space }\end{array}$ & $43 \%$ & $37 \%$ & yes \\
\hline & 17 & $\begin{array}{l}\text { Proportionality } \\
\text { Probability } \\
\text { System of linear } \\
\text { equations } \\
\end{array}$ & $39 \%$ & $16 \%$ & yes \\
\hline & 18 & $\begin{array}{l}\text { Probability } \\
\text { Combinatorics }\end{array}$ & $35 \%$ & $46 \%$ & yes \\
\hline
\end{tabular}


measured, and we have found a moderate negative correlation $(-0.52$ coefficient $)$ only between the length of the text and the efficiency of the problems. This result seems to contradict our previous statement, but we must not forget that the opportunity to skip one of the three problems in this part of the exam makes it even more difficult to make general statements.

\subsection{Higher level, Part I}

Part I of the higher level written final exam consists of four questions, each worth 10-14 points. In some cases these questions include sub-questions from the same topic group, and from different topics in some other cases.

Table 7 shows all the 16 questions between 2012 and 2015: their topic(s), their average efficiency based on the voluntary report and whether the given problem was related to everyday life situations, requiring modeling.

Based on the data of Table 7 we observe that:

- The efficiency of 12 out of 16 problems was between $75 \%$ and $88 \%$, meaning that the higher level candidates performed uniformly and well, regardless of the topic of the problem.

- The first questions in each paper served well as a "warm-up" for the candidates: in years 2012, 2013 and 2014 these problems produced the highest efficiency within the whole examination paper.

- The efficiency of problems requiring modeling is usually high (with year 2013 as an exception).

- Regarding the efficiency inside each topic, exercises with both higher and lower efficiency can be found in each topic group.

Let's take a closer look at the problems with the lowest efficiency:

- Question 2013/2 (efficiency 51\%). The low efficiency of this problem may be explained by several factors. First of all it was a so called "one-item" problem, meaning that it consisted of only one question, without any sub-questions. Therefore if the candidate could not start off at all or made a serious mistake at the beginning, then he/she could lose many points. Moreover we have seen before that problems in geometry usually have lower efficiency.

- Question 2013/4 (efficiency 55\%). The unusual way of posing the problem (daily interest rate) may have resulted in the low efficiency, as the mathematical content (calculating interests and mortgage payments) is certainly not expected to be a demanding topic. 
Table 7 . The topic and the average efficiency of the problems of Part

I in the higher level written final exam, 2012-2015

\begin{tabular}{|c|c|c|c|c|c|}
\hline Year & $\begin{array}{l}\text { Number } \\
\text { of the } \\
\text { question }\end{array}$ & Topic group & Topic & $\begin{array}{l}\text { Effici- } \\
\text { ency }\end{array}$ & $\begin{array}{l}\text { Required } \\
\text { modeling }\end{array}$ \\
\hline \multirow{4}{*}{2012} & 1 & Algebra & $\begin{array}{l}\text { Proportionality } \\
\text { Percentages }\end{array}$ & $92 \%$ & yes \\
\hline & 2 & Mixed & $\begin{array}{l}\text { Geometric progression } \\
\text { Probability }\end{array}$ & $83 \%$ & yes \\
\hline & 3 & Geometry & $\begin{array}{l}\text { Geometric calculations } \\
\text { in the space }\end{array}$ & $80 \%$ & \\
\hline & 4 & Functions & Elements of calculus & $83 \%$ & \\
\hline \multirow{4}{*}{2013} & 1 & Mixed & $\begin{array}{l}\text { Inequalities } \\
\text { Sets }\end{array}$ & $84 \%$ & \\
\hline & 2 & Geometry & $\begin{array}{l}\text { Geometric calculations } \\
\text { in the plane }\end{array}$ & $51 \%$ & yes \\
\hline & 3 & $\begin{array}{l}\text { Methods of } \\
\text { mathematical } \\
\text { reasoning }\end{array}$ & Graphs & $66 \%$ & \\
\hline & 4 & Functions & Financial calculations & $55 \%$ & yes \\
\hline \multirow{4}{*}{2014} & 1 & Mixed & $\begin{array}{l}\text { Quadratic equation } \\
\text { Combinatorics }\end{array}$ & $88 \%$ & \\
\hline & 2 & Mixed & $\begin{array}{l}\text { Algebra } \\
\text { Sets }\end{array}$ & $75 \%$ & \\
\hline & 3 & Mixed & $\begin{array}{l}\text { Geometric calculations } \\
\text { in the space } \\
\text { Statistics }\end{array}$ & $77 \%$ & yes \\
\hline & 4 & Functions & Differential calculus & $78 \%$ & \\
\hline \multirow{4}{*}{2015} & 1 & Algebra & Solving equations & $79 \%$ & \\
\hline & 2 & Mixed & $\begin{array}{l}\text { Proportions } \\
\text { Geometric calculations } \\
\text { in the plane }\end{array}$ & $86 \%$ & yes \\
\hline & 3 & Mixed & $\begin{array}{l}\text { Statistics } \\
\text { Percentages } \\
\text { Combinatorics }\end{array}$ & $79 \%$ & yes \\
\hline & 4 & Geometry & Coordinate geometry & $80 \%$ & \\
\hline
\end{tabular}


- Question 2013/3 (efficiency 66\%). Although 66\% is not an abnormally low efficiency, the knowledge required to solve the problem (connected graph, cycle graph, tree graph) did not appear in previous years' examination papers (although they are part of the curriculum). So the unusual topic may have caused the worse results.

We have examined, whether the efficiency is influenced by the existence of subquestions or not (the problem of the so-called "one-item" problems). Between 2012 and 2015 in Part I of the higher level written exam the following problems were "one-item" problems: 2013/1, 2013/2 and 2014/2. With regard to Table 7 we can say that two of them had the lowest efficiency in Part I in the given year.

\subsection{Higher level, Part II}

Part II of the higher level written final exam consists of five questions, worth 16 points each. The candidate has to solve four of the five problems and only these four are marked. These questions usually include sub-questions from different topic groups.

Table 8 shows all 20 questions of Part II of the higher level written exam between 2012 and 2015: their topic(s), the average efficiency based on the voluntary report, the ratio of those who did not choose the given problem (skip ratio), and if the given problem was related to everyday life situations, requiring modeling.

Based on the data of Table 8 we observe that:

- The efficiency of 18 out of 20 problems was between $54 \%$ and $74 \%$, meaning once again that the higher level candidates perform uniformly well, regardless to the topic of the problem.

- In case of the problem with the lowest efficiency (question 2014/8) the result may have been caused by the topic (coordinate geometry) on one hand. On the other hand in part a) a difficult proof was to be carried out, and although part b) was easier and could be solved without the result of part a), it is safe to assume that many candidates did not even start part b) after having failed in part a).

- It is clear, that the highest skip ratio is observed at problems in (coordinate) geometry.

- The average efficiency of problems requiring modeling (65\%) is nearly the same of those considered to be "purely" mathematical (64\%), and it is also obvious that these modeling problems produce lower skip ratio. 
Table 8. The topic, the average efficiency and the skip ratio of the problems of Part II in the higher level written final exam, 2012-2015

\begin{tabular}{|c|c|c|c|c|c|}
\hline Year & $\begin{array}{l}\text { Number } \\
\text { of the } \\
\text { question }\end{array}$ & Topic & $\begin{array}{l}\text { Effici- } \\
\text { ency }\end{array}$ & $\begin{array}{l}\text { Skip } \\
\text { ratio }\end{array}$ & $\begin{array}{l}\text { Required } \\
\text { modeling }\end{array}$ \\
\hline \multirow{5}{*}{2012} & 5 & \begin{tabular}{|l|} 
Geometric calculations in the \\
space \\
Number series \\
\end{tabular} & $63 \%$ & $15 \%$ & yes \\
\hline & 6 & $\begin{array}{l}\text { Combinatorics } \\
\text { Mathematical logic }\end{array}$ & $74 \%$ & $6 \%$ & \\
\hline & 7 & Coordinate geometry & $60 \%$ & $58 \%$ & \\
\hline & 8 & Probability & $66 \%$ & $12 \%$ & yes \\
\hline & 9 & $\begin{array}{l}\text { Geometric calculations in the } \\
\text { plane }\end{array}$ & $64 \%$ & $10 \%$ & \\
\hline \multirow{5}{*}{2013} & 5 & Coordinate geometry & $58 \%$ & $17 \%$ & \\
\hline & 6 & $\begin{array}{l}\text { Geometric calculations in the } \\
\text { plane } \\
\text { Infinite geometrical } \\
\text { series }\end{array}$ & $74 \%$ & $29 \%$ & \\
\hline & 7 & $\begin{array}{l}\text { Differential calculus } \\
\text { Statistics }\end{array}$ & $64 \%$ & $28 \%$ & yes \\
\hline & 8 & $\begin{array}{l}\text { Geometric calculations in the } \\
\text { plane } \\
\text { Probability } \\
\text { Combinatorics }\end{array}$ & $58 \%$ & $10 \%$ & yes \\
\hline & 9 & Probability & $54 \%$ & $17 \%$ & \\
\hline \multirow{5}{*}{2014} & 5 & Solving equations & $84 \%$ & $5 \%$ & \\
\hline & 6 & $\begin{array}{l}\text { Probability } \\
\text { Geometric calculations in the } \\
\text { space }\end{array}$ & $68 \%$ & $20 \%$ & yes \\
\hline & 7 & $\begin{array}{l}\text { Arithmetic progression } \\
\text { Combinatorics }\end{array}$ & $68 \%$ & $6 \%$ & yes \\
\hline & 8 & Coordinate geometry & $45 \%$ & $52 \%$ & \\
\hline & 9 & $\begin{array}{l}\text { Differential calculus } \\
\text { Probability }\end{array}$ & $63 \%$ & $17 \%$ & yes \\
\hline \multirow{5}{*}{2015} & 5 & Differential calculus & $69 \%$ & $6 \%$ & \\
\hline & 6 & Probability & $70 \%$ & $11 \%$ & yes \\
\hline & 7 & $\begin{array}{l}\text { Financial calculations } \\
\text { Infinite geometrical } \\
\text { series }\end{array}$ & $67 \%$ & $12 \%$ & yes \\
\hline & 8 & $\begin{array}{l}\text { Mathematical logics } \\
\text { Combinatorics } \\
\text { Geometry }\end{array}$ & $57 \%$ & $55 \%$ & \\
\hline & 9 & $\begin{array}{l}\text { Algebra } \\
\text { Geometrical calculations } \\
\text { in the space }\end{array}$ & $67 \%$ & $16 \%$ & \\
\hline
\end{tabular}


- Regarding the effectiveness of topic groups - in addition to the fact that most of the questions cannot be clearly classified into one of the topic groups - questions with both higher and lower efficiency can be found in each topic group again. Perhaps only problems in coordinate geometry show uniformly low efficiency.

Just like on the intermediate level, we have examined once again whether there is any connection between the length of the text, the efficiency and the skip ratio of the problems. It turns out that only low correlation can be measured among these criteria: we have only found a moderate negative correlation $(-0.57$ coefficient) between the efficiency and the skip ratio of a question. This means that if a question is skipped by more candidates, its efficiency is also lower in general. This is not surprising as higher level candidates are quite good at sizing up the difficulty of a problem: in 2012, 2014 and 2015 the questions with the highest skip ratio had the lowest efficiency. The same effect is reinforced by the experience that problems with a high skip ratio (either because it seems difficult or because of the unpopularity of its topic) are even less selected by the more talented candidates (as they are better in evaluating the difficulty of a problem), thereby the efficiency will be even lower.

We have also examined the efficiency of the "one-item" problems $(2012 / 7$ and 2013/5) in this part. In 2012 question 7 had the lowest efficiency in the whole examination paper, and in 2013 question 5 was among the less successful problems of part II.

\section{About candidates performing very low on the intermediate level}

In addition we have examined the lowest performing candidates' efficiency (those who got less than $20 \%$ overall for their written exam) in each question in Part I of the intermediate level examination paper. We have assorted the questions where these candidates - relative to their average results - performed better or worse, compared to all candidates. Table 9 and 10 show these questions.

Looking at the data of tables 9 and 10 we can observe that one of our findings for all the candidates is even more emphasized among the lowest performing candidates: they solve the geometrical problems even worse than all candidates - relative to their average results. And there is another specific topic where these candidates' performance is low: the simplification of algebraic fractions. 
Table 9. Questions in Part I of the intermediate written final exam where the lowest performing candidates performed relatively poorly, $2012-2015$

\begin{tabular}{|c|c|c|c|c|c|}
\hline \multirow{2}{*}{ Year } & \multirow{2}{*}{$\begin{array}{l}\text { Number of } \\
\text { the question }\end{array}$} & \multirow{2}{*}{ Topic group } & \multirow{2}{*}{ Topic } & \multicolumn{2}{|c|}{ Efficiency } \\
\hline & & & & of all & of low's \\
\hline \multirow{3}{*}{2012} & 7 & Geometry & Equation of a circle & $55 \%$ & $6 \%$ \\
\hline & 11 & Algebra & $\begin{array}{l}\text { Simplifying an algebraic } \\
\text { fraction }\end{array}$ & $48 \%$ & $2 \%$ \\
\hline & \multicolumn{2}{|c|}{ Part I average } & & $55 \%$ & $15 \%$ \\
\hline \multirow{3}{*}{2013} & 3 & Geometry & Calculations in the plane & $65 \%$ & $12 \%$ \\
\hline & 5 & Geometry & Trigonometry & $54 \%$ & $8 \%$ \\
\hline & \multicolumn{2}{|c|}{ Part I average } & & $57 \%$ & $23 \%$ \\
\hline \multirow{3}{*}{2014} & 6 & Algebra & Percentages & $59 \%$ & $9 \%$ \\
\hline & 11 & Geometry & Calculations in the plane & $60 \%$ & $9 \%$ \\
\hline & \multicolumn{2}{|c|}{ Part I average } & & $73 \%$ & $33 \%$ \\
\hline \multirow{3}{*}{2015} & 1 & Algebra & $\begin{array}{l}\text { Simplifying an algebraic } \\
\text { fraction }\end{array}$ & $45 \%$ & $7 \%$ \\
\hline & 10 & Geometry & Equation of a circle & $60 \%$ & $14 \%$ \\
\hline & \multicolumn{2}{|c|}{ Part I average } & & $56 \%$ & $26 \%$ \\
\hline
\end{tabular}

Table 10. Questions in Part I of the intermediate written final exam where the lowest performing candidates performed relatively well, $2012-2015$

\begin{tabular}{|c|c|c|c|c|c|}
\hline \multirow{2}{*}{ Year } & \multirow{2}{*}{$\begin{array}{c}\text { Number of the } \\
\text { problem }\end{array}$} & \multirow{2}{*}{ Topic group } & \multirow{2}{*}{ Topic } & \multicolumn{2}{|c|}{ Efficiency } \\
\hline & & & & of all & of low's \\
\hline \multirow{3}{*}{2012} & rhech & $\begin{array}{l}\text { Methods of } \\
\text { reasoning }\end{array}$ & Logics & $48 \%$ & $44 \%$ \\
\hline & 5 & Algebra & Percentages & $90 \%$ & $54 \%$ \\
\hline & \multicolumn{2}{|c|}{ Part I average } & & $55 \%$ & $15 \%$ \\
\hline \multirow{3}{*}{2013} & 1 & $\begin{array}{l}\text { Methods of } \\
\text { reasoning }\end{array}$ & Operation on sets & $93 \%$ & $76 \%$ \\
\hline & 11 & Statistics & Descriptive statistics & $84 \%$ & $58 \%$ \\
\hline & \multicolumn{2}{|c|}{ Part I average } & & $57 \%$ & $23 \%$ \\
\hline \multirow[t]{2}{*}{2014} & 1 & $\begin{array}{l}\text { Methods of } \\
\text { reasoning }\end{array}$ & Operation on sets & $83 \%$ & $62 \%$ \\
\hline & \multicolumn{2}{|c|}{ Part I average } & & $73 \%$ & $33 \%$ \\
\hline \multirow{3}{*}{2015} & 2 & Algebra & Number theory & $91 \%$ & $75 \%$ \\
\hline & 8 & $\begin{array}{l}\text { Methods of } \\
\text { reasoning }\end{array}$ & Graphs & $87 \%$ & $63 \%$ \\
\hline & \multicolumn{2}{|c|}{ Part I average } & & $56 \%$ & $26 \%$ \\
\hline
\end{tabular}


Among the questions with a relatively high efficiency we can find different topics, a common feature of these is probably the very simple mathematical content.

\section{Answers, conclusions}

Based on our research we can answer our questions asked at the beginning of this paper as follows:

1. At what topics do the candidates perform better and which ones are causing more difficulties?

It is quite clear that among the intermediate level candidates the problems in geometry cause the most difficulties. In the background of this phenomenon we assume on one hand the reduction of teaching geometry in primary and secondary schools in the last decades. On the other hand it is obvious that the problems in this topic are more difficult and require more complex knowledge and competencies than the average. Among the more successful topics we found - not surprisingly - algebra, and - maybe unexpectedly - the methods of mathematical reasoning, statistics and probability.

On the higher level the situation is more balanced. Candidates seem to perform steadily in all topics. However it stands out that problems from coordinate geometry often produce a high skip ratio in Part II, and even those who choose these problems solve them with a lower efficiency.

2. What is the efficiency of the topics (logic, graphs, statistics, probability theory), which are relatively new in the mathematics curriculum in Hungary?

As we have mentioned above: problems in these topics usually produce a low skip ratio and at the same time a high efficiency. There may be two different reasons for this. On one hand both teachers and textbooks showed a lot of development in these topics in the last 10-15 years. On the other hand it is true: for precautionary reasons the curriculum of the final exam contains only the very basic knowledge of these new topics, therefore solving these problems require less of the conventional mathematical (arithmetical, geometrical, algebraic) competencies. ${ }^{3}$

\footnotetext{
${ }^{3} \mathrm{As}$ a consequence the renewed curriculum of the final exams in mathematics expects - a bit - more in these topics from candidates from the year 2017 then it has before. http://www.oktatas.hu/pub_bin/dload/kozoktatas/erettsegi/vizsgakovetelmenyek2017/ matematika_vk_2017.pdf
} 
3. What is the efficiency of the problems related to everyday life situations of which some also requires modeling?

The description of the mathematics final exam specifies the ratio of problems related to everyday life situations or requiring modeling in examination papers $(30 \%-50 \%$ on intermediate level, $30 \%-40 \%$ on higher level). It is a common belief among teachers that students do not like these kind of problems, and they usually have difficulties solving them.

Our research has proved that - at least based upon data from exams between 2012 and 2015 - this belief is not confirmed. Candidates choose these kind of problems in large number on both levels, and the efficiency of these problems are often higher than that of the "pure" mathematical problems.

4. Are there topics, where those intermediate level candidates whose performance is the worst (under 20\%) are more efficient or less efficient than their average efficiency?

Our research proved that among the worst performers at the intermediate level exam problems in geometry have even worse results than the average.

\section{References}

[1] www.ketszintu.hu/publicstat.php.

[2] www.oktatas.hu/pub_bin/dload/unios_projektek/tamop318/meresmetodika/ Matematika.pdf.

[3] www.oktatas.hu/kozneveles/erettsegi/feladatsorok_vizsgatargyankent.

[4] Tanterv, tankönyv, vizsga, (Zs. Bánkkuti, J. Lukács, eds.), Oktatáskutató és Fejlesztő Intézet, Budapest, 2015.

[5] Tartalmi keretek a matematika diagnosztikus értékeléséhez, (B. Csapó, M. Szendrei, eds.), Nemzeti Tankönyvkiadó, Budapest, 2011.

[6] Cs. Csapodi and L. Koncz, A 2012. május-júniusi érettségi feladatsor és az egyes feladatok mérésmetodikai vizsgálata, Expanzió Humán Tanácsadó Kft, Budapest, 2013.

[7] Á. Einhorn, Feladatkönyv, Nemzeti Tankönyvkiadó, Budapest, 2012.

[8] Bevezetés a pedagógiai kutatás módszereibe, (I. Falus, ed.), Műszaki Könyvkiadó, Budapest, 2000.

[9] J. Lukács, Az új matematikaérettségi - három év tapasztalata, in: Tanulmányok az érettségiről. Hatásvizsgálat, tantárgyi vizsgák értékelése, feladatfejlesztés, (Zs. Bánkuti, J. Lukács, eds.), Oktatáskutató és Fejlesztő Intézet, Budapest, 2008, 187-206. 


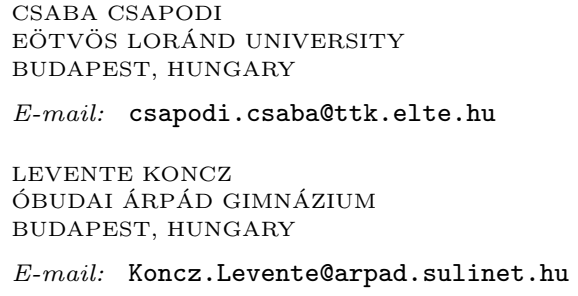

E-mail: Koncz.Levente@arpad.sulinet.hu

(Received March, 2016) 